\title{
PILLE, René-Marc, Adelbert von Chamisso vu de France 1805-1840. Genèse et réception d'une image
}

Christophe Duhamelle et Patrice Veit

\section{OpenEdition}

\section{Journals}

Édition électronique

URL : http://journals.openedition.org/ifha/2052

DOI : 10.4000/ifha.2052

ISSN : 2198-8943

Éditeur

IFRA - Institut franco-allemand (sciences historiques et sociales)

Référence électronique

Christophe Duhamelle et Patrice Veit, «PILLE, René-Marc, Adelbert von Chamisso vu de France

1805-1840. Genèse et réception d'une image », Revue de I'IFHA [En ligne], Date de recension, mis en ligne

le 01 janvier 1994, consulté le 22 septembre 2020. URL : http://journals.openedition.org/ifha/2052

DOI : https://doi.org/10.4000/ifha.2052

Ce document a été généré automatiquement le 22 septembre 2020.

(C)IFHA 


\title{
PILLE, René-Marc, Adelbert von Chamisso vu de France 1805-1840. Genèse et réception d'une image
}

\author{
Christophe Duhamelle et Patrice Veit
}

1 Pour l'étude des transferts culturels et de la constitution, à travers l'engouement littéraire, d'une image de l'Allemagne dans la France de la première moitié du XIXe siècle, la personnalité d'Adelbert von Chamisso offre d'évidence un grand intérêt et représente un cas complexe. Émigré de France à onze ans, Chamisso s'intégra si bien à son pays d'accueil qu'il y devint un botaniste réputé et l'un des poètes les plus populaires. Son vaste réseau épistolaire, ses attaches françaises, les hôtes (dont Chateaubriand) qui se succédèrent en sa demeure berlinoise, ses convictions libérales opposées aux conceptions étroitement nationales, lui conférèrent un rôle important de médiateur culturel.

2 Pourtant, la réception proprement dite de ses oeuvres littéraires en France, objet principal de cette étude fondée avant tout sur la correspondance de l'écrivain, resta assez limitée, malgré les traductions rapides de son récit Peter Schlemihl.

Christophe DUHAMELLE, Patrice VEIT 